\title{
PURIFICATION AND CHARACTERIZATION OF A BACTERIOCIN FROM ERWINIA CAROTOVORA
}

\author{
YOSHIFUMI ITOH, KAZUO IZAKI, AND HAJIME TAKAHASHI \\ Department of Agricultural Chemistry, Faculty of \\ Agriculture, Tohoku University, Sendai 980
}

(Received September 5, 1977)

\begin{abstract}
Syntheses of carotovoricin Er, a bacteriocin from Erwinia carotovora strain $\mathrm{Er}$, induced by mitomycin-C, was accompanied with cell lysis. Carotovoricin Er is a thermolabile particulate, sedimentable by centrifugation at $100,000 \times g$ for $60 \mathrm{~min}$, sensitive to sodium dodecyl sulfate, and unstable at acidic and basic $\mathrm{pH}$, indicating protein in nature. Carotovoricin $\mathrm{Er}$, however, is resistant to hydrolytic digestion by various proteolytic enzymes. Carotovoricin $\mathrm{Er}$ was purified approximately 70 fold by ammonium sulfate fractionation, DEAE-Sephadex A-50 column chromatography, Sepharose $2 \mathrm{~B}$ gel filtration, and sucrose density gradient centrifugation. Single peak of carotovoricin activity coincided with a protein peak in the sucrose density gradient. Negatively stained specimens of purified carotovoricin Er revealed that its structure consists of a contractible sheath, a core, and fibers, and resembled that of the tail part of bacteriophages.
\end{abstract}

Bacteriocins are proteins in nature, produced by certain bacteria, with properties of killing the same or closely related species of bacteria (1). A variety of bacteriocins have been found in many species of both gram-positive and -negative bacteria (2-4). Carotovoricin, a bacteriocin from Erwinia carotovora, was found by Hamon and Peron (5) in 1961. Some properties of carotovoricin have been reported by TsuYAma and his co-workers (6-8). However, it has not yet been purified as a homogeneous preparation. It has been reported from this laboratory that pectolytic enzyme formation of Erwinia aroidea is markedly stimulated when an inhibitor of DNA synthesis such as nalidixic acid, mitomycin-C, or bleomycin is added to the culture medium, and this pectolytic enzyme formation is accompanied with the induction of bacteriophage-like particles (9). Partial purification of these particles has been carried out in this laboratory and they were characterized as bacteriocins (10). We now wish to report further purification and properties 
of this bacteriocin, carotovoricin Er, which is produced by Erwinia carotovora Er. $^{1}$

\section{MATERIALS AND METHODS}

Bacterial strain. E. carotovora Er (AMS 6082) ${ }^{1}$ was used as the bacteriocinogenic strain. E. carotovora $645 \mathrm{Ar}^{1}$ was kindly supplied by Prof. H. Tsuyama of the Faculty of Agriculture, Iwate University, Morioka, and used as the indicator strain sensitive to carotovoricin Er.

Media and buffer. Bacteria were usually grown in a nutrient broth or M9 medium. The nutrient broth contained $1 \%$ each of meat extract (Kyokuto Seiyaku Co., Tokyo), Polypepton (Daigo Eiyo Co., Osaka), and $0.5 \% \mathrm{NaCl}$, pH 7.2. M9 medium contained per liter: $\mathrm{Na}_{2} \mathrm{HPO}_{4}, 7 \mathrm{~g} ; \mathrm{KH}_{2} \mathrm{PO}_{4}, 3 \mathrm{~g} ; \mathrm{NH}_{4} \mathrm{Cl}$, $1 \mathrm{~g} ; \mathrm{NaCl}, 0.5 \mathrm{~g} ; 0.1 \mathrm{mM} \mathrm{CaCl} 2 ; 1 \mathrm{mM} \mathrm{MgSO}_{4} ; 3 \mu \mathrm{M} \mathrm{FeCl}_{3}$, supplemented with $0.2 \%$ each of glucose and casein acid hydrolysate (Nissui Seiyaku Co., Tokyo). Nutrient soft agar was made by solidifying nutrient broth with $0.35 \%$ agar. M9 buffer used for dilution of bacteriocin solution had the same composition as M9 medium but carbon and nitrogen sources were omitted.

Assay of carotovoricin. A spot test was employed to determine bacteriocin activity. Successive 2- or 10 -fold dilution of the solution to be titrated in M9 buffer was prepared and $20 \mu \mathrm{l}$ at each dilution step was spotted on the surface of a soft nutrient agar ( $3 \mathrm{ml}$ per petri dish) containing about $2 \times 10^{7}$ cells of $E$. carotovora $645 \mathrm{Ar}$ per $\mathrm{ml}$. The spots were allowed to dry and the plates were incubated for 8 to $12 \mathrm{hr}$ at $30^{\circ}$. The reciprocal of the highest dilution that completely inhibited growth of the indicator strain was defined as bacteriocin activity in units per ml.

Preparation of crude carotovoricin Er. Mitomycin-C was added at the final concentration of $0.2 \mu \mathrm{g} / \mathrm{ml}$ to an exponentially growing culture of $E$. carotovora $\mathrm{Er}$ in M9 medium supplemented with glucose and casein acid hydrolysate, and the culture was incubated further for $6 \mathrm{hr}$ at $30^{\circ}$ with shaking. The crude preparation of carotovoricin Er was obtained from the culture fluid after centrifugation at $10,000 \times g$ for $10 \mathrm{~min}$ at $0^{\circ}$.

Electron microscopic observation. Purified native carotovoricin $(50 \mu \mathrm{g}$ as protein) or inactivated carotovoricin by freezing and thawing (100 $\mu \mathrm{g}$ as protein) was spun down by centrifugation at $100,000 \times g$ at $4^{\circ}$ for $60 \mathrm{~min}$. The precipitated carotovoricin was resuspended in $50 \mu \mathrm{l}$ of distilled water and then mixed with the same volume of $2 \%$ phosphotungustic acid, $\mathrm{pH} 7.0$. A loopful of this sample was loaded on a collodion-coated grid (200 mesh) and dried at room temperature. These specimens were observed with a Jeol-100B electron microscope, and photographed. Carotovoricin Er adsorbed to the cell surface of strain 645Ar was also

1 These strains were formerly classified as species of Erwinia aroideae, but according to the Bergey's Manual (8th edition) (11), they are classified as E. carotovora. Therefore, E. aroideae Er (AMS 6082) and E. aroideae 645Ar were renamed E. carotovora Er (AMS 6082) and E. carotovora $645 \mathrm{Ar}$, respectively. 
observed with the electron microscope. Exponentially growing cells of $645 \mathrm{Ar}$ strain in nutrient broth were harvested by centrifugation at $2,500 \times g$ at room temperature for $5 \mathrm{~min}$, washed twice with M9 buffer, and resuspended in the buffer at a concentration of $1 \times 10^{8}$ cells $/ \mathrm{ml}$. One $\mathrm{ml}$ of this cell suspension was mixed with the same volume of bacteriocin solution in M9 buffer (100 units/ml). The mixture was incubated at $30^{\circ}$ for $20 \mathrm{~min}$. The cells were collected by centrifugation at $2,500 \times g$ at room temperature for $5 \mathrm{~min}$, and resuspended in $0.5 \mathrm{ml}$ of distilled water. A specimen for the electron microscope was prepared as described above.

Protein determination. Protein was determined by the method of LownY et al. (12) using bovine serum albumin as a standard.

Chemicals and enzymes. Mitomycin-C was kindly supplied by the Kyowa Hakko Kogyo Co., Tokyo. Trypsin (from bovine pancreas, Type I) and $\alpha$ chymotrypsin (from bovine pancreas, Type II) were purchased from the Sigma Chemical Co., St. Louis U.S.A. Pronase E was purchased from the Kaken Kagaku Co., Tokyo.

\section{RESULTS}

\section{Induction and isolation of carotovoricin Er}

When mitomycin-C $(0.2 \mu \mathrm{g} / \mathrm{ml})$ was added to the exponentially growing culture of $E$. carotovora Er, a significant amount of bacteriocin was formed in the culture fluid. On the other hand, spontaneous synthesis of carotovoricin was undetectable in the absence of mitomycin-C. The inducible synthesis of carotovoricin was accompanied with cell lysis. Turbidity of the culture began to decrease at about $2.5 \mathrm{hr}$ after the addition of mitomycin-C and the bacteriocin activity began to increase from this time and reach the maximum after $6 \mathrm{hr}$, as shown in Fig. 1A and B. Majority of bacteriocin activity was found in the supernatant of the mitomycin-C-induced culture obtained by centrifugation, as shown in Fig. 1B.

\section{Properties of carotovoricin Er}

Some properties of carotovoricin Er were examined using crude preparations. When the crude lysate was centrifuged at $100,000 \times g$ at $4^{\circ}$ for $60 \mathrm{~min}$, the bacteriocin activity was completely recovered in the pellet. However, carotovoricin was found to pass through a Millipore filter (pore size, $0.45 \mu \mathrm{m}$ ). When the crude lysate was stored at $4^{\circ}$, only a little loss of the activity was found within a week and about $50 \%$ of the initial activity remained even after 1 month. The activity of this bacteriocin, however, was inactivated by heat. Most of the activity was lost by incubation at $50^{\circ}$ for $10 \mathrm{~min}$, and no activity remained after incubation at $80^{\circ}$ for $10 \mathrm{~min}$, as shown in Table 1 . Effect of various detergents on this bacteriocin was also tested. Sodium dodecyl sulfate completely inactivated carotovoricin, 


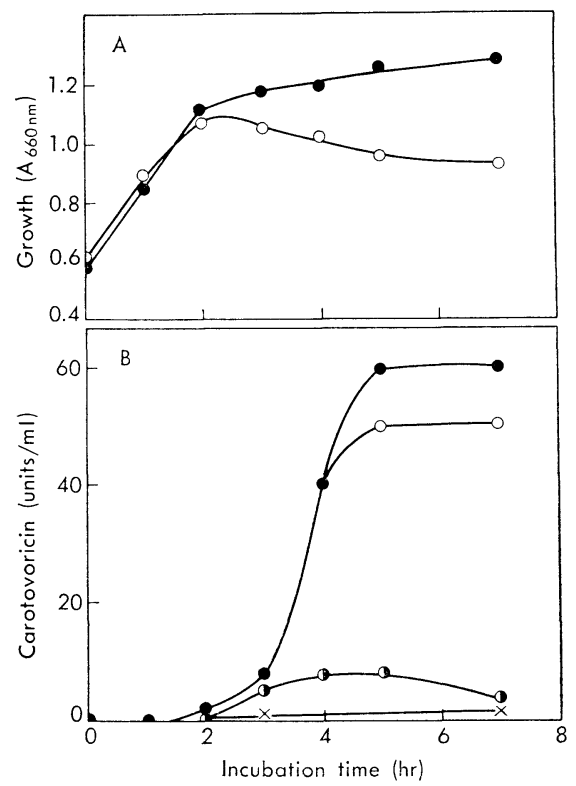

Fig. 1. A. Bacterial growth in the presence or absence of mitomycin-C $(0.2$ $\mu \mathrm{g} / \mathrm{ml})$.

- control; $O$, plus mitomycin-C at 0 time.

B. Bacteriocin formation in the presence or absence of mitomycin-C $(0.2 \mu \mathrm{g} / \mathrm{ml})$ and the localization of bacteriocin after centrifugation at $10,000 \times g$ at $4^{\circ}$ for $10 \mathrm{~min}$. $\times$, control; $\bigcirc$, total activity in the presence of mitomycin-C; $O$, activity in the supernatant; $\boldsymbol{O}$, activity in the pellet.

Table 1. Heat stability of carotovoricin Er.

\begin{tabular}{|c|c|c|}
\hline Treatment & $\begin{array}{l}\text { Activity } \\
\text { (units/ml) }\end{array}$ & $\begin{array}{c}\text { Relative activity } \\
(\%)\end{array}$ \\
\hline Control & 40 & 100 \\
\hline $50^{\circ} \quad(10 \mathrm{~min})$ & 1 & 2.5 \\
\hline $50^{\circ} \quad(20 \mathrm{~min})$ & $<1$ & $<2.5$ \\
\hline $80^{\circ} \quad(10 \mathrm{~min})$ & 0 & 0 \\
\hline $30^{\circ} \quad(1 \mathrm{hr})$ & 40 & 100 \\
\hline $30^{\circ} \quad(24 \mathrm{hr})$ & 20 & 50 \\
\hline $4^{\circ} \quad$ (30 days $)$ & 20 & 50 \\
\hline Freezing and thawing & 0 & 0 \\
\hline
\end{tabular}

Carotovoricin (40 units) in M9 buffer was incubated at various temperatures for various periods, and the residual bacteriocin activity was measured. The same sample was frozen at $-20^{\circ}$, kept overnight at $-20^{\circ}$, and thawed at $0^{\circ}$.

while deoxycholate or Triton X-100 did not affect the activity (Table 2). As shown in Fig. 2, this becteriocin is stable at neutral $\mathrm{pH}$ between 6.5 and 8.0 but unstable below or above this $\mathrm{pH}$ range. These results suggest that carotovoricin Er is protein in nature. However, no significant loss of activity was observed when 
Table 2. Effect of detergents on carotovoricin Er.

\begin{tabular}{cc}
\hline Detergent & $\begin{array}{c}\text { Activity } \\
\text { (units/ml) }\end{array}$ \\
\hline Control & 100 \\
Triton X-100 & \\
$2 \%$ & 100 \\
$0.2 \%$ & 100 \\
Sodium deoxycholate & \\
$1 \%$ & 100 \\
$0.2 \%$ & 100 \\
Sodium dodecyl sulfate & \\
$2 \%$ & 0 \\
$0.2 \%$ & 0 \\
\hline
\end{tabular}

Bacteriocin solutions (100 units $/ \mathrm{ml})$ containing various concentrations of different detergents and $0.05 \mathrm{M}$ Tris- $\mathrm{HCl}$ buffer, $\mathrm{pH} 7.4$ were incubated at $30^{\circ}$ for $60 \mathrm{~min}$. Bacteriocin was recovered by centrifugation at $100,000 \times g$ for $60 \mathrm{~min}$, suspended in M9 buffer, and its activity was determined.

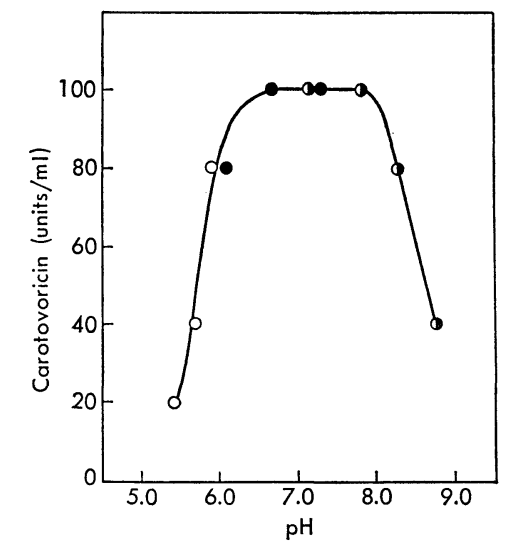

Fig. 2. pH stability of carotovoricin Er.

Carotovoricin Er (100 units) was dissolved in $1 \mathrm{ml}$ of various buffers and was incubated at $4^{\circ}$ for $24 \mathrm{hr}$. Carotovoricin was precipitated by centrifugation at $100,000 \times g$ at $4^{\circ}$ for $60 \mathrm{~min}$, and suspended in $\mathrm{M} 9$ buffer and remaining activity was determined. O, 0.05 м phosphate buffer; $\bullet, 0.05$ м citrate- $\mathrm{Na}_{2} \mathrm{HPO}_{4}$ buffer; $\boldsymbol{\oplus}, 0.05 \mathrm{M} \mathrm{NaOH}-\mathrm{H}_{3} \mathrm{BO}_{3-}$ $\mathrm{KCl}$ buffer.

the bacteriocin was incubated with proteolytic enzyme such as trypsin or $\alpha$ chymotrypsin at $30^{\circ}$ for $60 \mathrm{~min}$. About $40 \%$ of the initial activity, however, was lost by pronase E treatment as shown in Table 3. Essentially the same properties described above were revealed with the purified carotovoricin Er.

Purification of carotovoricin Er

Step 1: Ammonium sulfate fractionation. To 10 liters of the crude lysate, solid $\left(\mathrm{NH}_{4}\right)_{2} \mathrm{SO}_{4}$ was added to $50 \%$ saturation with continuous adjustment of 
Table 3. Effect of various proteolytic enzymes on carotovoricin Er.

\begin{tabular}{lc}
\hline \multicolumn{1}{c}{ Enzyme } & $\begin{array}{c}\text { Activity } \\
\text { (units/ml) }\end{array}$ \\
\hline Control & 100 \\
Trypsin & 90 \\
$\alpha$-Chymotrypsin & 90 \\
Pronase E & 60 \\
\hline
\end{tabular}

A mixture $(1 \mathrm{ml})$ containing bacteriocin (50 units $/ \mathrm{ml})$, each proteolytic enzyme $(0.5 \mathrm{mg} / \mathrm{ml})$, and $0.05 \mathrm{M}$ Tris- $\mathrm{HCl}$ buffer, $\mathrm{pH} 7.4$, were incubated at $30^{\circ}$ for $60 \mathrm{~min}$. After centrifugation at $100,000 \times g$ for $60 \mathrm{~min}$, bacteriocin in the pellets was suspended in $0.5 \mathrm{ml}$ of $\mathrm{M} 9$ buffer and its activity was determined.

$\mathrm{pH}$ to 7.0 with $\mathrm{NaOH}$. After standing at $4^{\circ}$ for $2 \mathrm{hr}$, the resulting precipitate was collected by centrifugation at $10,000 \times g$ at $4^{\circ}$ for $10 \mathrm{~min}$, and dissolved in $200 \mathrm{ml}$ of $0.02 \mathrm{M}$ phosphate buffer, $\mathrm{pH} 7.4$. It was dialysed against 2 liters of the same buffer at $4^{\circ}$ overnight, with a single change of the buffer during dialysis. Insoluble materials formed were removed by centrifugation at $10,000 \times g$ at $4^{\circ}$ for $10 \mathrm{~min}$ and a clear solution was obtained.

Step 2: DEAE-Sephadex A-50 column chromatography. The clear solution obtained as above was centrifuged at $66,000 \times g$ at $4^{\circ}$ for 90 min and the bacteriocin recovered in the pellet was suspended in $0.02 \mathrm{M}$ phosphate buffer, $\mathrm{pH} 7.4$. This sample (600 mg protein) was applied to a DEAE-Sephadex A-50 column $(2.2 \times$ $55 \mathrm{~cm}$ ) which had been equilibrated with $0.02 \mathrm{M}$ phosphate buffer, $\mathrm{pH} 7.4$. After

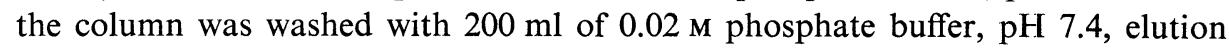
was made with a linear gradient of $\mathrm{NaCl}$ from 0 to $0.5 \mathrm{M}$ in $0.02 \mathrm{M}$ phosphate

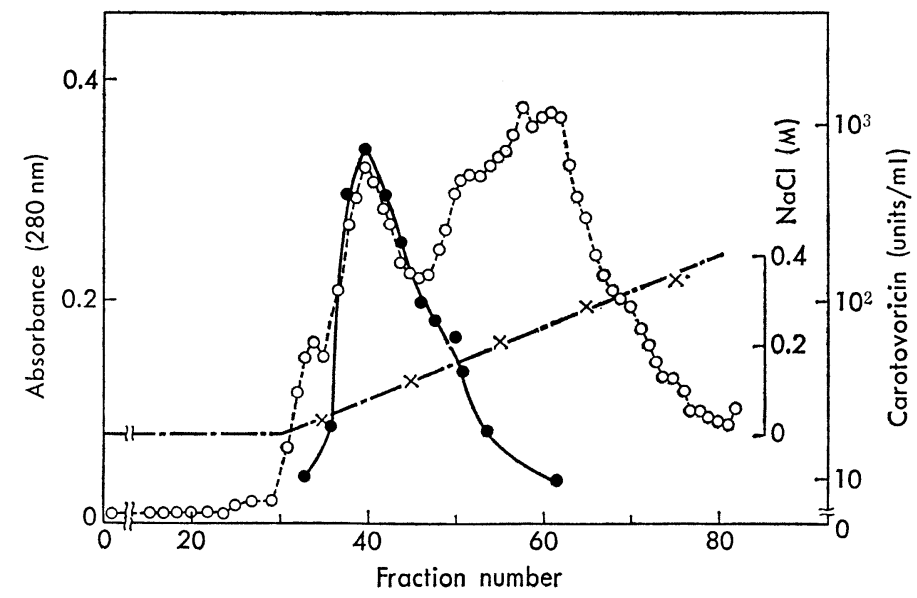

Fig. 3. Elution profile of carotovoricin Er on DEAE-Sephadex A-50 column chromatography.

See the text for details. O, absorbance at $280 \mathrm{~nm}$; $\bullet$, bacteriocin activity; $\times$, concentration of sodium chloride. 
buffer, $\mathrm{pH}$ 7.4. The mixing vessel and reservoir contained $400 \mathrm{ml}$ each of the buffers, and fractions of $10 \mathrm{ml}$ each were collected. The bacteriocin activity appeared at $0.1 \mathrm{M} \mathrm{NaCl}$ concentration as shown in Fig. 3. Fractions from 33 to 52 were pooled and subjected to the next procedure.

Step 3: Sepharose 2B gel filtration. The pooled fractions from the DEAESephadex A-50 column chromatography were concentrated by ultrafiltration with the aid of a Diafilter G-10T membrane (Japan Vacuum Engineering Co., Tokyo). The concentrated sample $(2 \mathrm{ml})$ was applied to a Sepharose $2 \mathrm{~B}$ column $(1.7 \times$ $123 \mathrm{~cm}$ ) which had been equilibrated with $0.05 \mathrm{M}$ phosphate buffer, $\mathrm{pH}$ 7.2. Elution was carried out with $0.05 \mathrm{M}$ phosphate buffer, $\mathrm{pH} 7.2$ and fractions of $5 \mathrm{ml}$ each were collected. Bacteriocin activity was eluted between fractions 30 and 50, as shown in Fig. 4.

Step 4: Sucrose density gradient centrifugation. Fractions between 32 and 48 from the Sepharose 2B gel filtration were collected and concentrated to $3 \mathrm{ml}$ by ultrafiltration. One $\mathrm{ml}$ of this sample was loaded on a density gradient from 5 to $20 \%$ sucrose in $0.05 \mathrm{~m}$ phosphate buffer, $\mathrm{pH} 7.2$. Centrifugation was carried out at $50,000 \times g$ at $4^{\circ}$ for $2 \mathrm{hr}$ in a Hitachi RPS- 25 rotor. After the run, 45 drops (about $1 \mathrm{ml}$ ) were collected from the bottom of each of the centrifuged tubes by sucking up through a needle with a peristatic pump. Carotovoricin activity of each fraction was determined by the spot test after 10-fold dilution with M9 buffer. Sedimentation profiles are shown in Fig. 5. A single peak of bacteriocin activity coincided with the protein peak. This fact suggests that carotovoricin is nearly homogeneous and pure. The purified carotovoricin was used for further study. All purification procedures described above were carried out at tem-

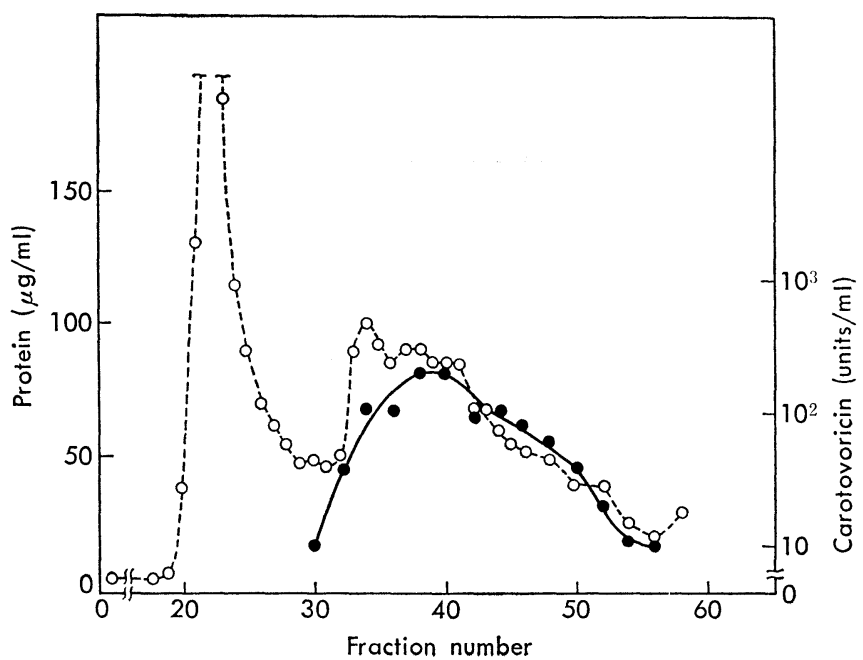

Fig. 4. Elution profile of carotovoricin Er on Sepharose 2B gel filtration. See the text for details; $O$, protein concentration; $\bullet$, bacteriocin activity. 


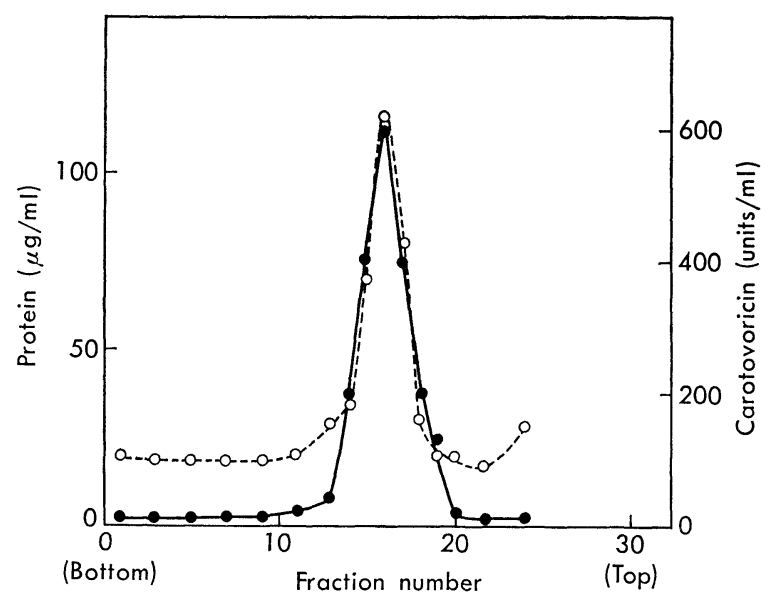

Fig. 5. Sedimentation profile of carotovoricin $\mathrm{Er}$ in sucrose density gradient centrifugation.

See the text for details. $\bigcirc$, protein concentration; $\bullet$, bacteriocin activity.

Table 4. Summary of purification.

\begin{tabular}{|c|c|c|c|c|c|}
\hline \multirow[b]{2}{*}{ Stage of purification } & \multicolumn{3}{|c|}{ Total } & \multirow[b]{2}{*}{$\begin{array}{l}\text { Specific activity } \\
\text { (units/mg) } \\
\text { of protein) }\end{array}$} & \multirow[b]{2}{*}{$\begin{array}{l}\text { Yield } \\
(\%)\end{array}$} \\
\hline & $\underset{(\mathrm{ml})}{\text { Volume }}$ & $\begin{array}{c}\text { Activity } \\
\left(\times 10^{3} \text { units }\right)\end{array}$ & $\begin{array}{l}\text { Protein } \\
\text { (mg) }\end{array}$ & & \\
\hline Crude lysate & 9,800 & 588 & 3,600 & 161 & 100 \\
\hline $\begin{array}{l}\left(\mathrm{NH}_{4}\right)_{2} \mathrm{SO}_{4} \text { precipitation } \\
\text { DEAE-Sephadex A-50 }\end{array}$ & 210 & 420 & 1,300 & 318 & 71 \\
\hline $\begin{array}{l}\text { column chromatography } \\
\text { Sepharose } 2 B\end{array}$ & 200 & 80 & 54.4 & 1,470 & 13.6 \\
\hline gel filtration & 108 & 53 & 10.3 & 5,150 & 9.0 \\
\hline $\begin{array}{l}\text { Sucrose density gradient } \\
\text { centrifugation }\end{array}$ & 25 & 30 & 2.6 & 11,540 & 5.1 \\
\hline
\end{tabular}

perature between $0^{\circ}$ and $4^{\circ}$. The purification is summarized in Table 4 . As shown, carotovoricin was purified approximately 70 -fold in $5 \%$ yield. This low recovery resulted from the loss of carotovoricin activity during the purification procedures.

Ultraviolet absorption spectrum of carotovoricin Er

Figure 6 shows the UV absorption spectrum of carotovoricin Er measured in phosphate buffer. Only one peak at $280 \mathrm{~nm}$ was observed showing typical absorption spectrum of a protein. Similar UV absorption spectrum was obtained when it was measured in $0.1 \mathrm{~N} \mathrm{NaOH}$.

Chemical composition of carotovoricin Er

DNA content measured by the method of BurTon (13) was negligible $(0.8$ 


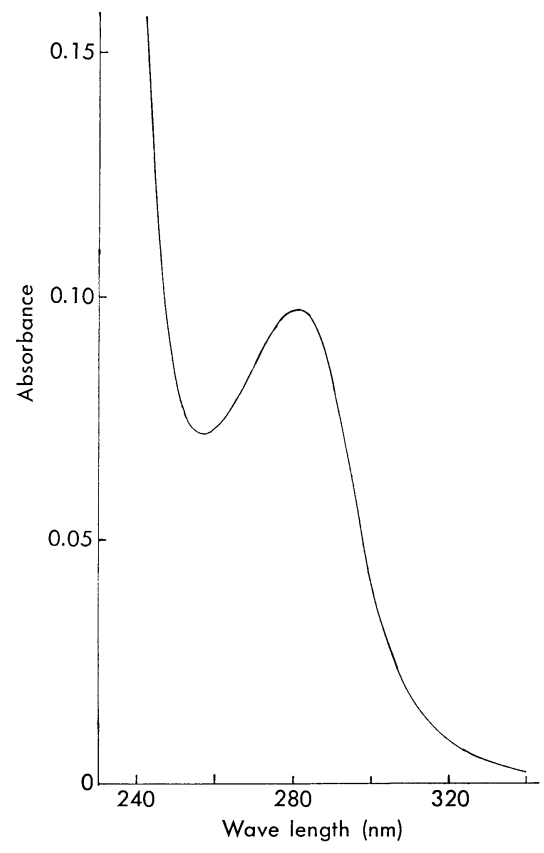

Fig. 6. Ultraviolet absorption spectrum of carotovoricin Er.

Carotovoricin $(250 \mu \mathrm{g}$ as protein) was dissolved in $2.5 \mathrm{ml}$ of $0.05 \mathrm{M}$ phosphate buffer, pH 7.2 and UV absorption spectrum was measured by a Hitachi 124 spectrophotometer.

$\mu \mathrm{g} / 104 \mu \mathrm{g}$ protein). A small amount of RNA $(7.3 \mu \mathrm{g} / 104 \mu \mathrm{g}$ protein) and carbohydrate $(10 \mu \mathrm{g}$ as glucose $/ 104 \mu \mathrm{g}$ protein) were detected by the method of MEJBAUM (14) and phenol reagent (15), respectively. The isoelectric point of carotovoricin Er was 5.30 as determined by the isoelectric focusing apparatus (LKBProducter, Sweden).

\section{Tryptic digestion of native and denatured carotovoricin Er}

Table 5 clearly demonstrates that purified carotovoricin is resistant to tryptic digestion. The denatured carotovoricin, however, is easily digested by trypsin.

\section{Morphology of carotovoricin Er}

A photomicrograph of negative-stained carotovoricin Er with $1 \%$ phosphotungustic acid is shown in Fig. 7. Carotovoricin Er consisted of a sheath, a core, and fibers, and resembled that of bacteriophage tail part. Size of the core was $1600 \AA$ in length and $60 \AA$ in diameter. The length of sheath was also $1600 \AA$ and its outer diameter was $185 \AA$. The sheath had a cylindrical structure around the core and appeared to be capable of contraction. In Fig. 7, the sheath of some carotovoricins are seen in the state of contraction, and most carotovoricins which were inactivated by freezing and thawing (Fig. 8) or adsorbed to the cell surface 
Table 5. Effect of trypsin on native and denatured carotovoricin Er.

\begin{tabular}{lcc}
\hline & $\begin{array}{c}\text { Microgram protein } \\
\text { in } 0.5 \mathrm{ml} \text { of mixture }\end{array}$ & $\begin{array}{c}\text { Absorbance at } 750 \mathrm{~nm}^{a} \\
\text { in the supernatant }\end{array}$ \\
\hline Native carotovoricin & 57 & 0 \\
Heat denatured $^{b}$ carotovoricin & 57 & 0.140 \\
Bovin serum albumin $^{\text {ing }}$ & 200 & 0.150 \\
\hline
\end{tabular}

The reaction mixture $(0.5 \mathrm{ml})$ containing $100 \mu \mathrm{g}$ of trypsin and $57 \mu \mathrm{g}$ of native or heat-denatured purified carotovoricin or $200 \mu \mathrm{g}$ of bovine serum albumin in $0.05 \mathrm{M}$ Tris- $\mathrm{HCl}$ buffer, $\mathrm{pH} 7.5$, was incubated at $30^{\circ}$ for $60 \mathrm{~min}$. One-tenth $\mathrm{ml}$ of perchloric acid was added to the reaction mixtures to the final concentration of $5 \%$ and the resulting precipitate was removed by centrifugation. To $0.4 \mathrm{ml}$ of each supernatant, $0.1 \mathrm{ml}$ of $4 \mathrm{~N} \mathrm{NaOH}$ was added and soluble peptides were determined by the method of LowrY et al. (12).

a Reaction mixture containing only $100 \mu \mathrm{g}$ of trypsin was treated similarly as described above, and the solution obtained was used as the reference in spectrophotometric assay.

$b$ Heat inactivation was carried out at $80^{\circ}$ for $10 \mathrm{~min}$.

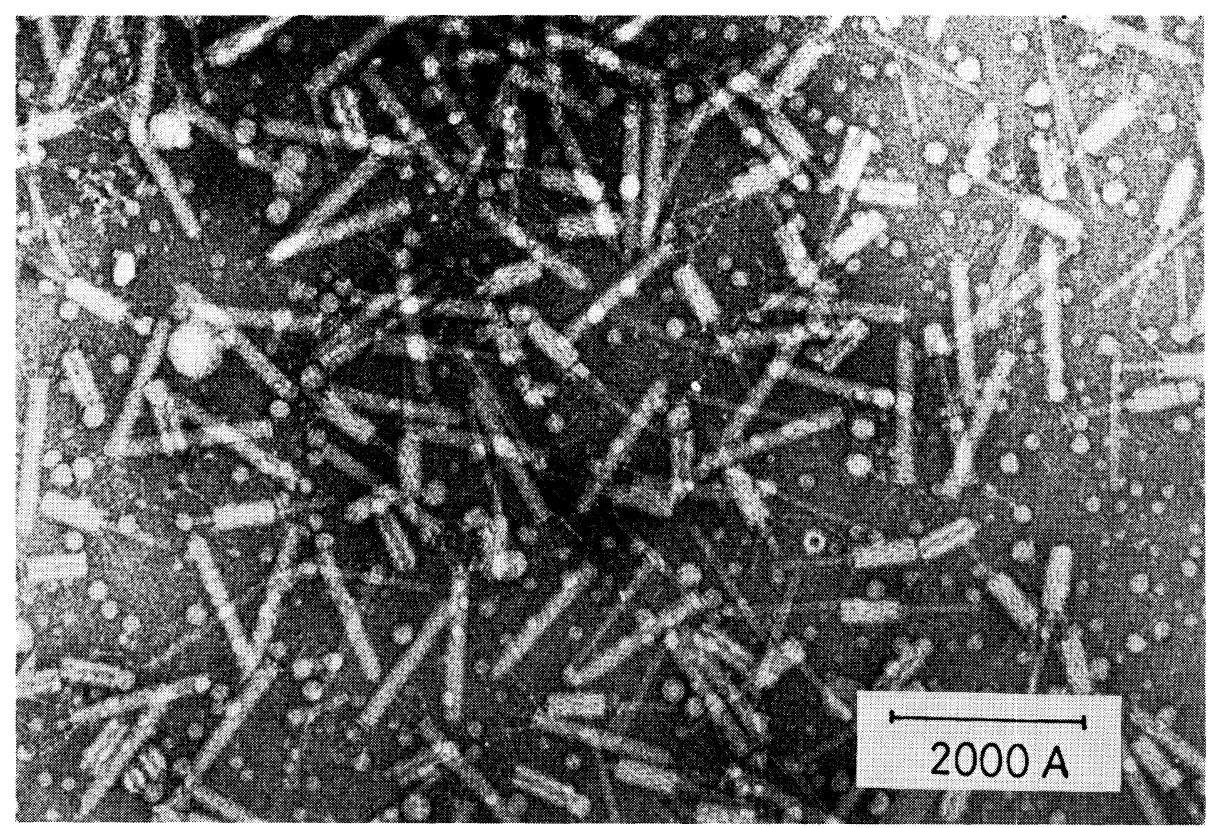

Fig. 7. Electron photomicrograph of negatively stained purified carotovoricin Er.

of the sensitive strain (Fig. 9) had a contracted sheath. The length and outer diameter of the contracted sheath were $680 \AA$ and $230 \AA$, respectively The number of fibers was not clearly counted but its length was about $800 \AA$. Carotovoricins with contracted sheath or contracted sheath detached from the core in Fig. 7 might have been formed from the complete carotovoricin Er with non-contracted sheath during the negative staining procedures. 


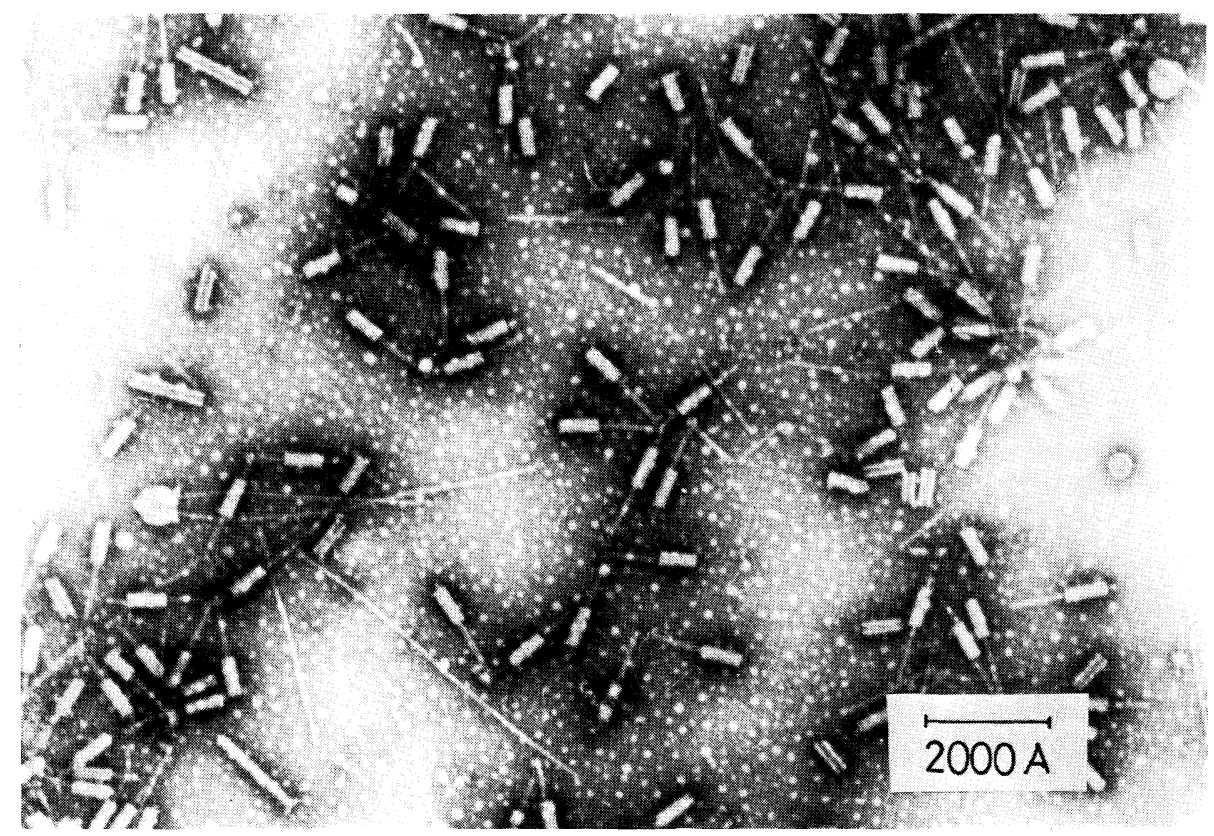

Fig. 8. Electron photomicrograph of inactivated carotovoricin Er by freezing and thawing.

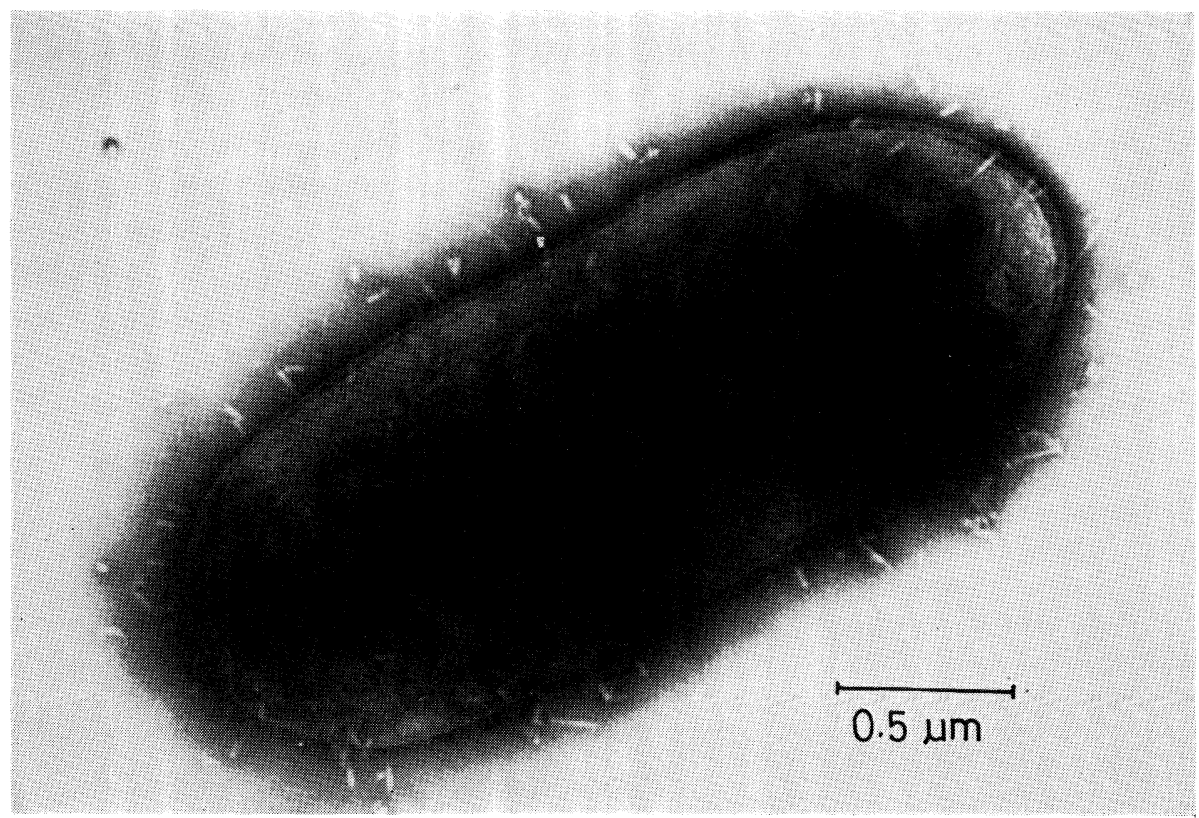

Fig. 9. Adsorption of carotovoricin Er on the cell surface of a sensitive strain, strain 645Ar. 


\section{DISCUSSION}

Synthesis of carotovoricin Er, a bacteriocin of Erwinia carotovora strain Er, was induced by mitomycin-C and accompanied with cell lysis. Carotovoricin $\mathrm{Er}$ is a high molecular weight compound, sedimentable by centrifugation at $100,000 \times g$ for $60 \mathrm{~min}$, unstable at acidic or basic $\mathrm{pH}$, inactivated by sodium dodecyl sulfate, and thermolabile. It shows a typical absorption spectrum of a protein. These results suggest that carotovoricin $\mathrm{Er}$ is protein in nature. A small amount of RNA and carbohydrate detected in purified carotovoricin are possibly due to contamination of cell envelopes or ribosomes. Carotovoricin Er was found to be resistant to various proteolytic enzymes such as trypsin and $\alpha$ chymotrypsin. On the other hand, heat-denatured carotovoricin was easily digested by trypsin. These enzymes might not be accessible to their substrate site for the complex structure of native carotovoricin. The mode of formation and characteristics of carotovoricin $\mathrm{Er}$ are similar to those of clostocin $\mathrm{O}$ and $\mathrm{M}$, bacteriocins from Clostridium saccharoperbutylacetonicum (16), or pyocin R, a bacteriocin from Pseudomonas aeruginosa $(17,18)$. These bacteriocins are quite different from colicins, bacteriocins from Escherichia coli (1-3). Although colicins are synthesized inducibly by mitomycin-C, their syntheses are not accompanied with cell lysis. Colicins are relatively small in molecular size $\left(4.5-10 \times 10^{4}\right.$ daltons) and are sensitive to hydrolytic action of proteolytic enzymes.

Structure of carotovoricin Er visualized with an electron microscope closely resembled that of pyocin $\mathrm{R}$ which has been extensively studied by IsHII et al. (19). Pyocin $\mathrm{R}$ consists of a sheath, a core, a base plate, and fibers, and the sheath is found to be capable of contraction. Pyocin R, which is defective in contraction, has no killing activity (20). As shown in this report, the sheath of carotovoricin $\mathrm{Er}$ also appears to be capable of contraction. Carotovoricins inactivated by freezing and thawing or those adsorbed to their sensitive cells showed contracted sheaths. Therefore, contraction of the sheath may be essential for the killing action of carotovoricin Er. Many bacteriophages and bacteriocins were found to be adsorbed to their specific receptors on the cell surfaces of their sensitive strains. As judged by the photomicrograph, the receptors for carotovoricin Er appear to be distributed all over the cell surface of the sensitive $645 \mathrm{Ar}$ strain.

We are grateful to the Kyowa Hakko Kogyo Co., for the generous supply of mitomycin-C and to Prof. H. Tsuyama for providing bacterial strains. We also thank Dr. S. Kamimiya for his useful suggestions and Mr. T. Satoh of this Faculty for his skillful technical help in the operation of the electron microscope. This investigation was supported in part by a Grant-in-Aid for Scientific Research (056023) from the Ministry of Education, Science and Culture to one of the authors (H. T.).

\section{REFERENCES}

1) M. Nomura, Ann. Rev. Biochem., 21, 259 (1967).

2) P. Reeves, Bacteriol. Rev., 29, 24 (1965). 
3) P. ReEves, The Bacteriocins: Molecular Biology, Biochemistry, and Biophysics, Vol. 11, Springer-Verlag, New York (1972), p, 87.

4) J. R. TAgg, A. S. Dajani, and L. W. Wannamaker, Bacteriol. Rev., 40, 722 (1976).

5) Y. Hamon and Y. Peron, C.R. Acad. Sci., 253, 913 (1961).

6) Y. Endo and Y. TsuYama, J. Fac. Agr. Iwate Univ., 11, 205 (1973).

7) F. Nakatani and Y. Tsuyama, J. Fac. Agr. Iwate Univ., 11, 245 (1974).

8) Y. Endo and H. Tsuyama, Annu. Phytopath. Soc. Japan, 41, 40 (1975).

9) H. Tomizawa and H. TaKahashi, Agric. Biol. Chem. (Tokyo), 35, 191 (1971).

10) S. KamimiYa, K. Izaki, and H. Takahashi, Agric. Biol. Chem. (Tokyo), 41, 911 (1977).

11) R. E. Buchanan and N. E. GibBons, In Bergey's Manual of Determinative Bacteriology, 8th Ed., ed. by R. A. Lelliott, The Williams and Wilkins, Co., Baltimore (1974), p. 337.

12) O. H. Lowry, N. J. Rosebrough, A. L. Parr, and R. J. Randall, J. Biol. Chem., 193, 265 (1951).

13) K. Burton, Biochem. J., 62, 315 (1956).

14) W. Mejbaum, Z. Physiol. Chem., 258, 117 (1939).

15) M. Dubois, K. A. Gilles, J. K. Hamilton, P. A. Rebers and F. Smith, Anal. Chem., 28, 350 (1956).

16) S. Ogata, O. Mihara, Y. Ikeda, and M. Hongo, Agric. Biol. Chem. (Tokyo), 36, 1413 (1972).

17) M. Kageyama, J. Biochem. (Tokyo), 55, 49 (1964).

18) K. Ikeda, M. Kageyama, and F. Egami, J. Biochem. (Tokyo), 55, 54 (1964).

19) S. IshiI, Y. Nishi, and F. Egami, J. Mol. Biol., 13, 428 (1965).

20) T. Shinomiya, M. Ohsumi, and M. Kageyama, J. Bacteriol., 124, 1508 (1975). 